\title{
Physiological stress and pathology in European whitefish (Coregonus lavaretus) induced by subchronic exposure to environmentally relevant densities of Planktothrix rubescens
}

\author{
Bernhard Ernst, Stefan J. Hoeger, Evelyn O’Brien, Daniel R. Dietrich* \\ Environmental Toxicology, University of Konstanz, P.O. Box X-918, D-78457 Konstanz, Germany
}

Received 14 November 2006; received in revised form 27 December 2006; accepted 17 January 2007

\begin{abstract}
Planktothrix rubescens belongs to the most ubiquitous cyanobacterial species in mesotrophic and oligotrophic lakes in the pre-alpine regions. In most of these lakes, coregonids are among the dominant species of the ichthyofauna with great importance for the professional fishery. A possible link between the occurrence of toxic Planktothrix blooms and the recurrent slumps in coregonid yields has been suggested. Indeed, acute toxic effects of microcystins and other cyanobacterial toxins have been shown for various fish species. However, chronic exposure scenarios appear to be more common and thus more environmentally realistic than acute intoxications. The aim of this study was therefore to investigate the physiological stress response and organ pathology in coregonids sub-chronically exposed to ambient water containing low, medium and high $P$. rubescens densities, known to be typical of pre-alpine lakes. Coregonid hatchlings were exposed in four tanks containing 0 (sham-control) and approximately 1500 (low), 15,000 (medium) and 55,000 (high) P. rubescens cells/ml for up to 28 days. Temperature, oxygen concentration, $\mathrm{pH}$-value, $P$. rubescens cell density and microcystin concentration were recorded and the fish were observed for behavioural changes and examined for parasite infestations. Gill ventilation rates, general condition factors and mortalities were determined and liver, kidney, gut and gill were assessed histopathologically and immunhistologically.

Depending on the cell density, exposed fish showed behavioural changes, including increased ventilation rates possibly representing a physiological stress response. Susceptibility to ectoparasitic infestation and increased mortality in exposed fish suggested $P$. rubescens associated effects on fish fitness. Histopathological alterations in liver, gastrointestinal tract and kidney, which were also immunopositive for microcystin suggested causality of tissue damage and the presence of microcystins. In contrast, observed gill pathology appeared to result primarily from mechanical abrasion and irritation due to ectoparasitic infestation. The current exposure experiment confirmed the hypothesis that subchronic and chronic exposure to low cyanobacterial cell densities and hence microcystins can exacerbate physiological stress and sustained pathological alterations in exposed coregonids. The study therefore supports the theory that $P$. rubescens blooms may be causal to the observed weight reduction and hence fitness of coregonids in pre-alpine lakes such as Lake Ammersee (Germany).
\end{abstract}

(C) 2007 Elsevier B.V. All rights reserved.

Keywords: Fish; Microcystin; Planktothrix; Coregonid; Cyanobacteria; Whitefish; Stress; Pathology

\section{Introduction}

Toxic cyanobacteria occur ubiquitously in fresh and coastal waters. Due to their ability to produce highly toxic metabolites, i.e., various neurotoxins and potent protein phosphatase inhibitors, e.g., microcystins, mass occurrences of cyanobacteria have been associated with mortality of wild and domestic animals including fish (Briand et al., 2003; Jewel et al., 2003;

\footnotetext{
* Corresponding author. Tel.: +49 7531 883518; fax: +49 7531883170. E-mail address: Daniel.Dietrich@uni-konstanz.de (D.R. Dietrich).
}

Rodger et al., 1994; Toranzo et al., 1990). To date, at least 46 cyanobacterial species are known to produce toxins (Sivonen and Jones, 1999), of which the microcystin-producing Planktothrix is one of the most important genera in temperate climates. Planktothrix occur in eutrophic waters, producing surface or whole water-body blooms during winter circulation and metalimnic bloom layers during lake stratification in summer (Walsby et al., 1998). However, Planktothrix rubescens can also occur in mesotrophic and even oligotrophic lakes that have recently undergone an anthropogenically induced phase of reoligotrophication (Ernst et al., 2006b; Jacquet et al., 2005). As a consequence, $P$. rubescens has been a predominant species 
of the phytoplankton community in several monomictic and dimictic European lakes, especially in the alpine and pre-alpine regions for several decades (Gammeter et al., 1997; Krupa and Czernas, 2003; Kucklentz et al., 2001; Wehrli and Wüest, 1996). P. rubescens blooms can reach and maintain cell densities of more than 50,000 cells $/ \mathrm{ml}$ over several months, calculated based on filament length and a unit cell size and spectrofluorimetric measurements (Ernst et al., 2001; Hoeger et al., 2005; Jacquet et al., 2005).

In many pre-alpine lakes, coregonids (Coregonus sp.) are among the dominant species of the ichthyofauna with great importance for the professional fishery. Over the past decades, recurrent slumps in yearly yields of coregonids caused by reduced fish weight and fitness has been observed to coincide with the appearance of $P$. rubescens blooms in Swiss and German lakes (Braun, 1953; Ernst et al., 2001). Therefore, a possible link between the occurrence of toxic Planktothrix blooms and the recurrent changes in growth and population dynamics of coregonids has been suggested (Ernst et al., 2001, 2006a).

Toxic effects of microcystins and other cyanobacterial toxins occur in various fish species, including Salmoniformes, Siluriformes, Cypriniformes as well as Perciformes (summarised in Malbrouck and Kestemont, 2006). However, differences in fish species sensitivity to toxic cyanobacteria and cyanobacterial toxins (primarily microcystin-LR: MC-LR) are known to exist (Fischer and Dietrich, 2000; Tencalla, 1995). Uptake of cyanobacterial toxins by fish has been shown to occur primarily via oral ingestion of toxins or toxic cyanobacterial cells and to a reduced if not negligible extent from toxin uptake by the gill epithelium (Bury et al., 1995; Tencalla et al., 1994). Previous studies have shown that fish exposed to acutely toxic concentrations of microcystins or bloom material show pathological changes in the liver, kidney, gut and gill, and associated effects, such as increased serum liver enzyme values. In addition, behavioural changes and changes in the development of fish have been reported (summarised in Malbrouck and Kestemont, 2006). However, most of these findings were restricted to acute studies, often employing toxin or bloom exposure routes that do not realistically reflect environmentally relevant situations.

The microcystin concentrations found in water bodies (Hoeger et al., 2005 and references therein) are, with some exceptions, generally lower than the known acute lethal concentrations for fish (Landsberg, 2002). Furthermore, cyanobacterial blooms, especially those of $P$. rubescens, can last up to several months (Ernst et al., 2001; Jacquet et al., 2005; Salmaso, 2000). Thus, a subchronic or chronic exposure scenario appears to be quite common and hence more environmentally realistic, while acute intoxications may have less ecological relevance. However, apart from a few studies suggesting oxidative stress (direct assessment of reactive oxygen species overproduction, assessment of oxidation products or determination of changes in antioxidant mechanisms and detoxication) as a causative factor in cyanobloom or cyanotoxin induced fish pathology (Bláha et al., 2004; Jos et al., 2005; Li et al., 2005), more in-depth information on subchronic or chronic effects of microcystin exposure in fish are rare.
Coregonids exposed to a single oral dose of $80,000 P$. rubescens cells show an enhanced physiological stress (e.g., increased ventilation rates) as well as pathological changes characteristic of microcystin intoxications (Ernst et al., 2006a). This suggests that prolonged (subchronic or chronic) exposure of coregonids to high $P$. rubescens filament densities could cause increased physiological stress and thus also reduced growth. The aim of this study was therefore to investigate the physiological stress response (ventilation rate, behavioural changes, blood glucose levels) and organ pathology in hatchling coregonids (Coregonus lavaretus L.) sub-chronically immersed in P. rubescens densities known to occur in pre-alpine lakes, i.e.,

(i) a low density of approximately 1500 cells $/ \mathrm{ml}$, regularly occurring in large zones of the waterbody for the majority of the year without the overt presence of $P$. rubescens blooms/layers;

(ii) a medium density of approximately 15,000 cells $/ \mathrm{ml}$ which is often observed in metalimnic layers and sometimes in large zones of the water-body during winter circulation, and

(iii) a high density of approximately 55,000 cells $/ \mathrm{ml}$, often occurring in metalimnic $P$. rubescens layers.

\section{Material and methods}

\subsection{Chemicals}

All reagents and solvents were of analytical or chromatographic grade and were purchased from Fluka (Switzerland), Merck (Germany), Riedel de Haen (Germany), Roth (Germany) or Sigma-Aldrich (Germany).

\subsection{Cultivation and $P$. rubescens toxin characterisation}

P. rubescens was originally isolated from a Lake Ammersee seston sample in autumn 2002 (Hoeger et al., in press) and cultivated in BG11 medium according to the method described by Rippka et al. (1979). The microcystin-LR equivalent content and microcystin congener composition of this $P$. rubescens culture was previously described by Ernst et al. (2006a) and was shown to contain $2-3 \mu \mathrm{g} \mathrm{MC-LR}$ equiv. $/ \mathrm{mg}$ d.w. and to predominantly consist of demethylated microcystin-RR variants.

\subsection{Fish exposure}

Hatchlings of European whitefish (Coregonus lavaretus L.; approx. weight: $6 \mathrm{~g}$; approx. length: $10 \mathrm{~cm}$ ) were obtained from the Lake Ammersee Fisheries Cooperative (Germany). Fish were distributed randomly into four 1001 tanks ( 24 coregonids/tank). Five coregonids sampled immediately prior to random distribution were taken as an initial control and used for comparison with the sham-control and exposure groups (see below). Tanks were filled with tap water and aerated using a commercial aquarium aeration pump. Ten percent of the tank water volume was replaced by fresh water daily. Fish were 


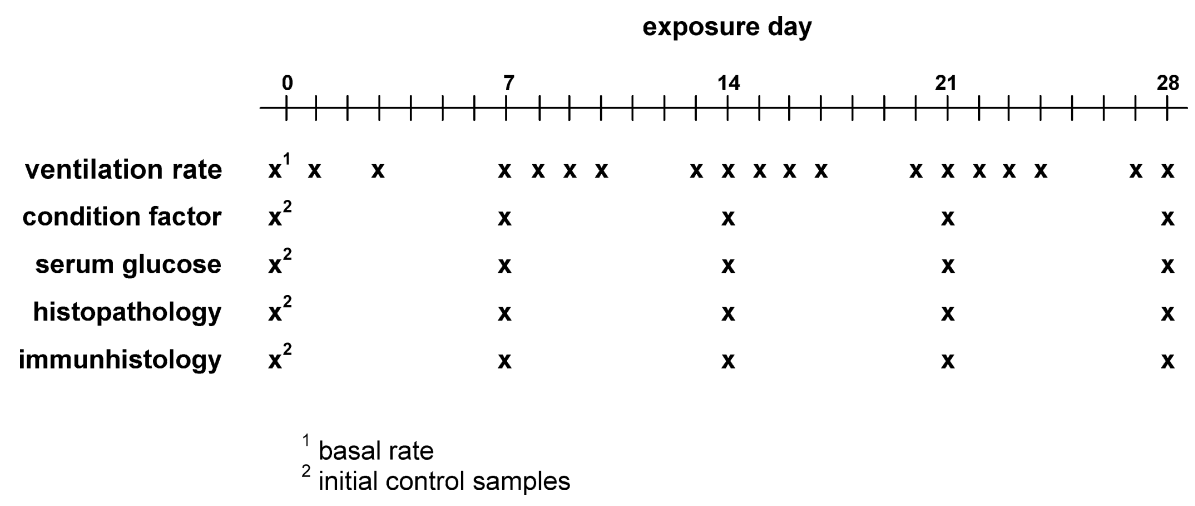

Fig. 1. Time points of parameter determination during the 28 day experiment.

fed (15\% of body weight) with frozen daphnia and chironomid larvae (Honka, Germany) once per day.

After acclimatisation $(24 \mathrm{~h})$, three tanks (A, B and C) were exposed to $P$. rubescens filament densities corresponding to approximately 1500 (low), 15,000 (medium) and 55,000 P. rubescens cells $/ \mathrm{ml}$ (high), respectively. The remaining tank (tank Co) served as corresponding sham-control, i.e., without addition of $P$. rubescens filaments.

\subsection{Monitoring of experimental parameters throughout the experiment}

Tank temperatures were measured twice daily, while oxygen concentrations were determined at least three times per week. $\mathrm{pH}$-values were determined on two separate occasions during the exposure.

\subsubsection{P. rubescens cell densities}

$P$. rubescens cell densities were determined in the $P$. rubescens culture and daily in the exposure tanks via image processing as described by Ernst et al. (2006b). Subsequent to water renewal, densities were readjusted to the initial filament density via replenishment of $P$. rubescens from the stock culture.

\subsubsection{Microcystin concentration}

The MC-LR equivalent concentration (MC-LR $\left.\mathrm{equiv}_{\text {. }}\right)$ in the tank water was determined on days 3, 6, 9, 13, 16, 17, 20, 22 and 24 in water from tanks A, B and C and on day 6, 13, 17 and 24 in water from the sham-control tank. For this purpose $1.5 \mathrm{ml}$ tank water were taken through a $0.2 \mu \mathrm{m}$ syringe filter and stored at $-20^{\circ} \mathrm{C}$. Total MC-LR equivalent concentration (MC-LR equiv. $\left._{\text {. }}\right)$ in a given water sample was analysed using the Adda-ELISA kit (Abraxis, USA, see also Fischer et al., 2001) according to the manufacturer's instructions. The analytical results (MC-LR equiv $_{\text {iv }}$ concentration) were finally combined to give a time-weighted average $\mathrm{MC}-\mathrm{LR}_{\text {equiv. }}$ concentration per tank over the duration of the experiment.

\subsection{Mortality, parasite infestations, behavioural observations and ventilation rates}

Fish were observed daily for behavioural changes and overt parasite infestation. Dead fish were registered, removed from the tanks, and withdrawn from the experimental cohort used for subsequent analyses.

The ventilation rate of control and exposed fish was determined before (group specific basal rate) and at 18 different time-points during the exposure (Fig. 1), by counting the opercular movement of four individuals per tank for $15 \mathrm{~s}$ each. Ventilation rates determined were multiplied by four, thus giving the ventilation rate per min.

\subsection{Sampling and experimental procedures}

On days 7, 14, 21 and 28, six fish were sampled from each tank (sham-control and exposure groups). All fish (also including fish of the initial control) were assessed for macroscopical anomalies and then analysed using the experimental parameters shown in Fig. 1 and described below.

\subsubsection{Weight}

Wet weight was determined on a fine balance (PB3002; Mettler, Germany).

\subsubsection{Length}

Length (nose-tip to tail) was determined to the nearest $\mathrm{mm}$ using a centimetre ruler.

\subsubsection{Condition factor}

Condition factor $(\mathrm{CF})$ was calculated as $\mathrm{CF}=$ weight $[\mathrm{g}] \times(\text { length }[\mathrm{mm}])^{-3} \times 10^{5}$ (Barton et al., 2002).

\subsubsection{Serum glucose concentration}

Serum glucose concentration was determined in blood taken from the caudal vein, using a $1 \mathrm{ml}$ syringe and a $0.40 \mathrm{~mm} \times 20 \mathrm{~mm}$ needle (Braun, Germany). Blood serum was isolated via coagulative precipitation at $4{ }^{\circ} \mathrm{C}$ for $12 \mathrm{~h}$ and subsequent centrifugation $\left(4000 \times g ; 10 \mathrm{~min}, 4^{\circ} \mathrm{C}\right)$. The supernatant (serum) was frozen and stored at $-20^{\circ} \mathrm{C}$ until measurement. Serum glucose was determined using an automatic sensor (Accu-Chek, Roche, USA) according to the manufacturer's instructions.

\subsubsection{Histopathology}

A representative tissue sample of liver, kidney, gill and hindgut was dissected from each fish, placed into a labelled tis- 
sue cassette and briefly fixed in 4\% PBS-buffered formalin. In addition, fresh (non-fixed) gill samples were inspected microscopically for accumulation of $P$. rubescens filaments between the gill lamellae. PBS-buffered formalin fixed tissues were routinely embedded in paraffin, sectioned to 3-5 $\mu \mathrm{m}$ and mounted on microscope slides (RCC Ltd., Switzerland). Histopathological assessment was carried out using hematoxylin and eosin (H\&E) stained sections by light microscopy at 40-400-fold magnification. Pathological changes were classified as none (0), mild (1), moderate (2), strong (3) and severe (4), including intermediate classes (e.g., $0.5,1.5$ ).

\subsubsection{Immunohistochemical determination of microcystin}

Sections of liver, kidney, gill and intestine mounted on polysin-coated glass slides were deparaffinised in $100 \%$ xylol, rehydrated in descending ethanol concentrations $(100,95$ and $70 \%$ ) and then incubated with $1 \mathrm{mg} / \mathrm{ml}$ type XIV bacterial protease (Sigma-Aldrich, Germany) in PBS for antigen-demasking at $37^{\circ} \mathrm{C}$ for $10 \mathrm{~min}$. Endogenous peroxidase was blocked with $3 \% \mathrm{H}_{2} \mathrm{O}_{2}$ at room temperature for $15 \mathrm{~min}$. Endogenous biotin was blocked using a commercial blocking kit (Avidin/Biotin Blocking Kit, BioGenex, USA). Slides were further blocked with normal goat serum (1:500 in PBS; Vector Laboratories, $\mathrm{UK}$ ) for $20 \mathrm{~min}$ and a casein solution (Power Block ${ }^{\mathrm{TM}}$, BioGenex, USA) for $10 \mathrm{~min}$ at room temperature. Adda-antiserum (\#824, see Fischer et al., 2001) was diluted 1:5000 in Power Block $^{\mathrm{TM}}$ and applied to the tissue section in a humidified atmosphere for $16 \mathrm{~h}$ at $4{ }^{\circ} \mathrm{C}$. Antigen-antiserum complexes were visualised using a HRP-labelled, biotin-streptavidin amplified detection system with the 3-amino-9-ethylcarbazole (AEC) chromogen (Super Sensitive ${ }^{\mathrm{TM}}$, BioGenex, USA). Sections were counterstained at room temperature for $6 \mathrm{~min}$ with Mayer's hematoxylin (Sigma-Aldrich, Germany), rinsed with tap water and mounted using Crystal/Mount ${ }^{\mathrm{TM}}$ (Biomeda, USA) and Shandon Histomount ${ }^{\mathrm{TM}}$ (Thermo Electron Corporation, Germany). A section was classified to be MC-positive when MC-positive areas were above background chromogen staining and the positive staining areas were congruently observable in two independently stained serial sections from the same tissue sample block. Immunopositive staining was classified as none $(0)$, sporadic $(+)$, pronounced $(++)$, and extensive $(+++)$.

\subsection{Statistical analyses}

Normally, animals exposed in groups can potentially influence each other and as such, cannot be considered as independent replicates. However, increasing the number of replicate tanks with a low number of fish was impracticable and would have provided for additional variables (stress, dispersion of filament densities). Therefore each individual fish of a given treatment group (sham-control or exposure group) was treated as if it represented an independent experimental replicate of that treatment group. Statistical analyses were carried out using GraphPad Prism $4^{\circledR}$ (USA) Software. Values were given as the mean \pm standard deviation (S.D.) for condition factor and ventilation rate. Pathological changes in the respective tissues are given as median \pm mean absolute deviation (MAD) of the individual ranks of at least three individuals examined.

\subsubsection{Ventilation rate}

A one-way ANOVA followed by Tukey's multiple comparison test was employed to compare the ventilation rates observed in each tank before addition of $P$. rubescens. Statistical differences in ventilation rates were analysed using a one-way ANOVA followed by Dunnett's multiple comparison test to compare ventilation rates of the control fish and the rates of the fish immersed in low, medium and high $P$. rubescens densities at each time point.

\subsubsection{Condition factor}

Condition factors were tested for statistical differences using an one-way ANOVA followed by Dunnett's multiple comparison test to compare condition factors of control fish and the condition factor of the fish exposed to low, medium and high $P$. rubescens densities at each time-point.

\subsubsection{Histopathology}

Ranking of pathological changes was tested for statistical differences using the non-parametric Mann-Whitney test.

Significant differences were determined at the $p<0.01$ and $p<0.05$ level for all analyses and are indicated as ${ }^{* *}$ for $p<0.01$ and ${ }^{*}$ for $p<0.05$.

\section{Results}

\subsection{Hydrological parameters, microcystin concentrations and $P$. rubescens cell densities}

Temperature in the tanks ranged between 15 and $20^{\circ} \mathrm{C}$. Oxygen consistently exceeded $8 \mathrm{mg} / \mathrm{l}$ (corresponding to more than $90 \%$ saturation) in all tanks during the experiment (Table 1). The $\mathrm{pH}$-values determined were 7.9 and 8.0 in tanks Co \& $\mathrm{A}$ and in tanks B \& C, respectively. The $95 \%$ confidence interval of $P$. rubescens mean cell densities determined were 1353-2066 cells $/ \mathrm{ml}$ in tank A, 13,657-15,493 cells $/ \mathrm{ml}$ in tank $\mathrm{B}$, and $52,845-59,122 \mathrm{cells} / \mathrm{ml}$ in tank $\mathrm{C}$ (Table 1). The timeweighted mean MC-LR equiv. concentrations determined were $0.3,1.8$ and $11.0 \mu \mathrm{g} / \mathrm{l}$ for exposure tanks $\mathrm{A}, \mathrm{B}$, and $\mathrm{C}$, respectively. No MC was detectable in water samples of tank Co (sham-control).

\subsection{Mortality, parasite infestation, behavioural observations and ventilation rates}

Some coregonids died during the course of the experiment: two (8\% mortality) in the low dosed (tank A), three (13\% mortality) in the medium dosed (tank B) and six (25\% mortality) in the high dosed (tank C) treatment. In contrast to this, only one fish (4\% mortality) died in the corresponding sham-control tank. Fish mortality primarily occurred during the first 2 weeks of the exposure experiment.

In the third week of exposure, some fish presented with an ectoparasitical infestation with Ichthyophthirius sp. The severity 
Table 1

Hydrological parameters and time-weighted microcystin concentrations in the tanks containing no (sham-control), low, medium and high $P$. rubescens densities

\begin{tabular}{llccc}
\hline & Tank Co, sham-control & Tank A, low & Tank B, medium & Tank C, high \\
\hline Temperature $\left({ }^{\circ} \mathrm{C}\right)$ & $18.7 \pm 1.0(57)$ & $18.3 \pm 1.0(57)$ & $18.4 \pm 1.1(57)$ & $17.1 \pm 1.2(57)$ \\
Oxygen $(\%)$ & $97.4 \pm 2.7(14)$ & $95.9 \pm 2.4(14)$ & $98.4 \pm 2.3(14)$ & $96.6 \pm 2.5(14)$ \\
$P_{\text {rubescens }}(\mathrm{cells} / \mathrm{ml})$ & & $1709 \pm 1372(57)$ & $14575 \pm 3536(57)$ & $55984 \pm 12091(57)$ \\
MC-LR $_{\text {equiv. }}(\mu \mathrm{g} / \mathrm{l})$ & n.d. $(04)$ & $0.3 \pm 0.19(26)$ & $1.8 \pm 1.46(26)$ & $11.0 \pm 4.10(26)$ \\
\hline
\end{tabular}

Values are given as mean \pm S.D.; the number of analysed samples $(n)$ is given in parentheses.

of the infestation was highest in tank $\mathrm{C}$ (highest $P$. rubsescens density) with approximately $50 \%$ of individuals being affected. No infestation was observed in the sham-control tank. In order to avoid ectoparasitical infestation associated fish mortality compromising the completion of the exposure experiment, remaining coregonids of all treatments (including the sham-control) were therapeutically treated via immersion in a $4 \% \mathrm{NaCl}$-solution for $0.5 \mathrm{~min}$.

Following exposure to medium and high $P$. rubescens cell densities (tank B and C), the coregonids immediately responded with broad, irregular gaping and a few of the exposed fish appeared to regurgitate (initiated flow-reversal) through the gills. Broad, irregular gaping was also observed in coregonids exposed to low $P$. rubescens densities (tank A), however, not until day 13 and to a noticeably lower degree than in tanks B and C. Coregonids in tanks $\mathrm{B}$ and $\mathrm{C}$ displayed a more hectic swimming behaviour and appeared more susceptible to startling when compared to the low dose and the corresponding sham-control fish.
Furthermore, fish in tanks B and C appeared increasingly disoriented and presented with an upwardly inclined posture over the duration of the experiment.

The ventilation rates determined before the $P$. rubescens filament exposure (basal rates) were statistically indistinguishable in all four tanks (Table 2). The $95 \%$ confidence interval of the overall mean ventilation rate determined in tank Co (sham-control) was $120-127$ beats/min. The $95 \%$ confidence interval of the overall mean ventilation rates determined in the $P$. rubescens containing tanks were 131-150, 143-163, and 161-178 beats/min in tank A, B and C, respectively. Statistical analyses demonstrated that ventilation rates of the coregonids in the $P$. rubescens containing tanks were significantly elevated compared to the corresponding sham-control fish. Ventilation rates in tank $\mathrm{C}$ were significantly elevated from the beginning of the experiment at all time points, while in tank B this was the case as of day 9 of the exposure only. In tank A there was also a significant increase of ventilation rates as of day 10 , however,

Table 2

Ventilation rates determined in coregonids exposed in no (sham-control), low, medium and high P. rubescens cell densities for up to 28 days

\begin{tabular}{|c|c|c|c|c|}
\hline Ventilation rate (counts/min) & Tank Co, sham-control & Tank A, low & Tank B, medium & Tank C, high \\
\hline \multicolumn{5}{|l|}{ Week 1} \\
\hline Basal rate & $92 \pm 3.3$ & $95 \pm 3.8$ & $96 \pm 3.3$ & $95 \pm 2.0$ \\
\hline Day 1 & $113 \pm 3.8$ & $109 \pm 6.0$ & $114 \pm 2.3$ & $129 \pm 3.8^{* *}$ \\
\hline Day 3 & $116 \pm 3.3$ & $119 \pm 6.8$ & $128 \pm 5.7$ & $145 \pm 8.9^{* *}$ \\
\hline Day 7 & $116 \pm 5.7$ & $112 \pm 6.5$ & $112 \pm 3.3$ & $154 \pm 17.7^{* *}$ \\
\hline \multicolumn{5}{|l|}{ Week 2} \\
\hline Day 8 & $129 \pm 5.0$ & $122 \pm 5.2$ & $137 \pm 2.0$ & $153 \pm 14.7^{\text {*** }}$ \\
\hline Day 9 & $127 \pm 6.0$ & $122 \pm 5.2$ & $144 \pm 7.3^{* *}$ & $181 \pm 6.0^{* *}$ \\
\hline Day 10 & $111 \pm 2.0$ & $127 \pm 11.9^{*}$ & $143 \pm 8.9^{* *}$ & $185 \pm 6.0^{* * *}$ \\
\hline Day 13 & $127 \pm 5.0$ & $154 \pm 20.3^{*}$ & $171 \pm 5.0^{* *}$ & $182 \pm 6.9^{* *}$ \\
\hline Day 14 & $129 \pm 6.8$ & $143 \pm 10.5$ & $151 \pm 8.9^{* *}$ & $165 \pm 5.0^{* * *}$ \\
\hline \multicolumn{5}{|l|}{ Week 3} \\
\hline Day 15 & $133 \pm 6.0$ & $162 \pm 10.1^{* *}$ & $176 \pm 4.6^{* *}$ & $174 \pm 7.7^{* * *}$ \\
\hline Day 16 & $123 \pm 5.0$ & $152 \pm 6.5^{* *}$ & $160 \pm 15.7^{* *}$ & $175 \pm 6.0^{* *}$ \\
\hline Day 17 & $128 \pm 5.7$ & $145 \pm 6.0^{* *}$ & $149 \pm 7.6^{* *}$ & $159 \pm 6.0^{* * *}$ \\
\hline Day 20 & $136 \pm 8.6$ & $152 \pm 5.7^{*}$ & $171 \pm 8.9^{* *}$ & $177 \pm 8.2^{* * *}$ \\
\hline Day 21 & $123 \pm 9.5$ & $153 \pm 6.0^{* *}$ & $172 \pm 9.8^{* *}$ & $174 \pm 5.2^{* *}$ \\
\hline \multicolumn{5}{|l|}{ Week 4} \\
\hline Day 22 & $127 \pm 17.4$ & $149 \pm 7.6$ & $173 \pm 11.9^{* *}$ & $187 \pm 6.8^{* *}$ \\
\hline Day 23 & $134 \pm 4.0$ & $181 \pm 2.0^{* *}$ & $184 \pm 5.7^{* *}$ & $193 \pm 11.5^{* *}$ \\
\hline Day 24 & $120 \pm 8.6$ & $156 \pm 11.3^{* *}$ & $164 \pm 5.7^{* *}$ & $189 \pm 21.3^{* *}$ \\
\hline Day 27 & $117 \pm 7.6$ & $127 \pm 7.6$ & $153 \pm 8.9^{* *}$ & $155 \pm 13.2^{* *}$ \\
\hline Day 28 & $118 \pm 5.2$ & $144 \pm 7.3^{* *}$ & $153 \pm 10.0^{* *}$ & $169 \pm 10.5^{* *}$ \\
\hline
\end{tabular}

Values are given as mean \pm S.D. of four observed individuals for each time point. Significant differences between control fish and exposed fish are indicated $\left({ }^{*} p<0.05\right.$ and $\left.{ }^{* *} p<0.01\right)$ for each time point. 
Table 3

Condition factors of coregonids immersed in no (sham-control), low, medium and high P. rubescens densities for up to 28 days

\begin{tabular}{|c|c|c|c|c|}
\hline Condition $\left[\mathrm{g} \times \mathrm{mm}^{-3} \times 10^{5}\right]$ & Tank Co, sham-control & Tank A, low & Tank B, medium & Tank C, high \\
\hline Initial & $0.59 \pm 0.035(5)$ & & & \\
\hline Day 7 & $0.55 \pm 0.045(5)$ & $0.56 \pm 0.014(6)$ & $0.56 \pm 0.026(6)$ & $0.55 \pm 0.019$ \\
\hline Day 14 & $0.53 \pm 0.029(6)$ & $0.54 \pm 0.032(5)$ & $0.54 \pm 0.048(5)$ & $0.50 \pm 0.047(4)$ \\
\hline Day 21 & $0.50 \pm 0.037(6)$ & $0.52 \pm 0.031(6)$ & $0.49 \pm 0.030(6)$ & $0.51 \pm 0.030(6)$ \\
\hline Day 28 & $0.50 \pm 0.053(6)$ & $0.50 \pm 0.047(5)$ & $0.47 \pm 0.038$ & $0.51 \pm 0.044(5)$ \\
\hline
\end{tabular}

Values are given as mean \pm S.D.; the number of analysed individuals $(n)$ is given in parentheses

the relative increase appeared not as pronounced as in tanks B and $\mathrm{C}$ (Table 2).

\subsection{Condition factor and serum glucose}

The condition factors decreased with increasing time in all treatments including the sham-control tank (Table 3). This decrease appeared to occur most rapidly in the highest dosed treatment (tank C), being already apparent at day 14 . However, differences between condition factors of the sham-control and exposed coregonids were not statistically significant due to the high inherent variability of this parameter.

The limited serum sample volumes resulted in no reliable determination of serum glucose levels (data not shown).

\subsection{Histopathology}

\subsubsection{Liver}

Neither initial control fish nor coregonids from the shamcontrol showed histopathological changes in the liver beyond the normal range observed in coregonids of this age group. In contrast, $P$. rubescens exposed coregonids presented with focal liver pathology consisting of hepatocytes with granulated cytosol, reduced glycogen stores, disintegration of the parenchymal liver architecture, cell dissociation, heterochromaty, chromatin margination, necrosis and apoptosis, ruptured vessels, and dilated sinusoids, predominantly peripheral to central veins (Fig. 2). The range and severity of pathological changes were exposure time and $P$. rubescens cell density dependent.
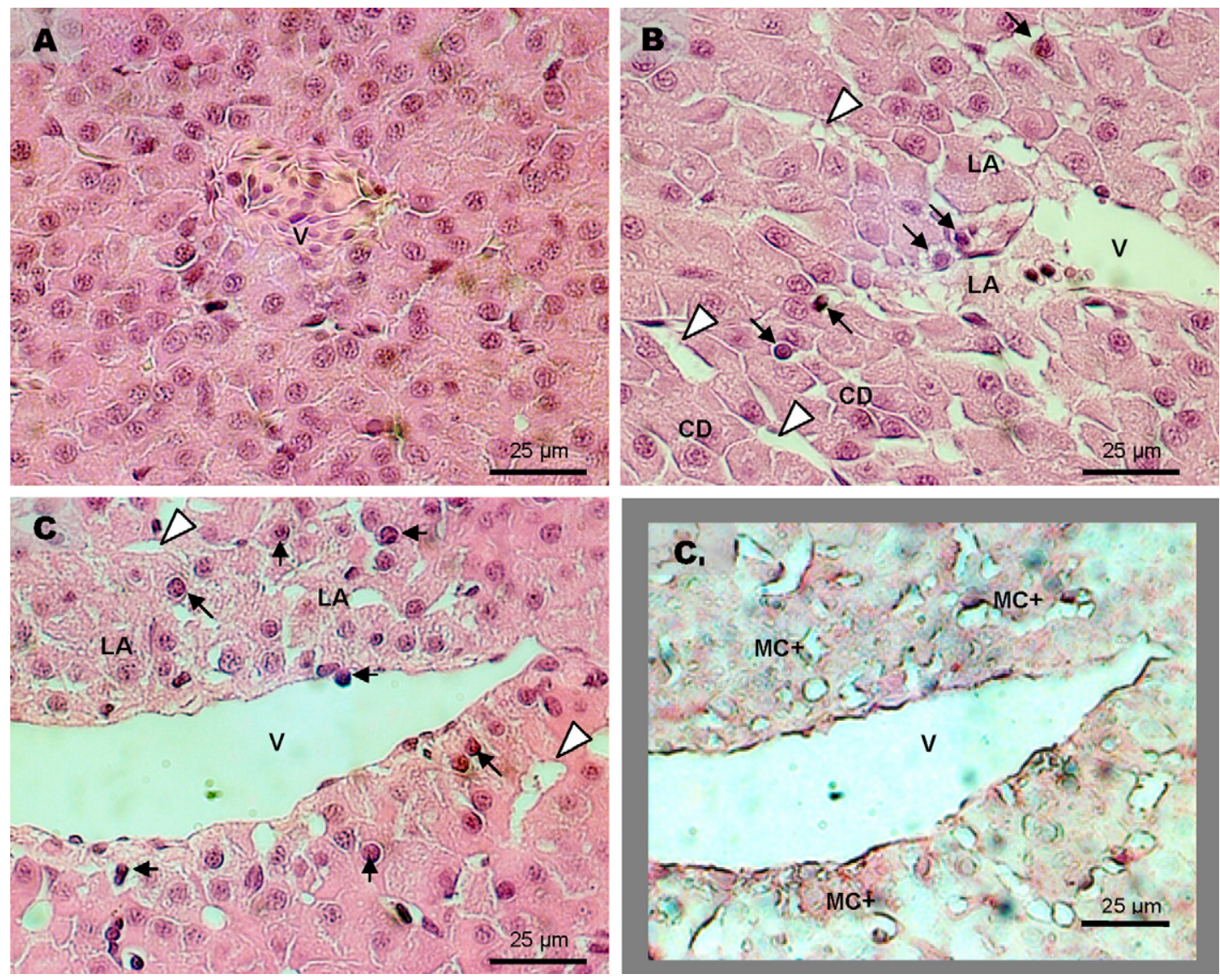

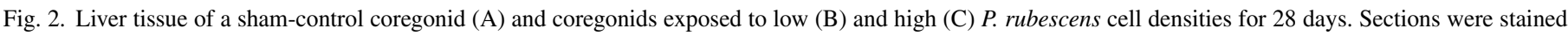

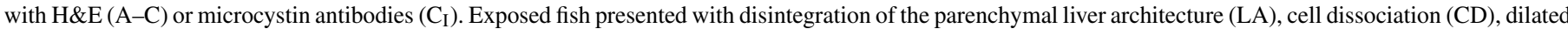

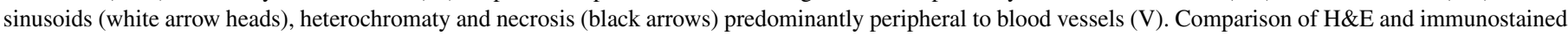
sections $\left(\mathrm{C}\right.$ and $\left.\mathrm{C}_{\mathrm{I}}\right)$ demonstrates the presence of microcystin $(\mathrm{MC}+)$ in histologically altered tissue sections. 
Table 4

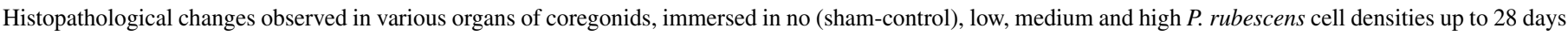

\begin{tabular}{|c|c|c|c|c|}
\hline Day & Liver & Kidney & Hindgut & Gill \\
\hline \multicolumn{5}{|l|}{ Initial } \\
\hline 0 & $1.0 \pm 0.36(5)$ & $1.5 \pm 0.24(5)$ & $0.5 \pm 0.24(5)$ & $1.0 \pm 0.32(5)$ \\
\hline \multicolumn{5}{|c|}{ Sham-control } \\
\hline 7 & $0.8 \pm 0.28$ & $0.5 \pm 0.36(5)$ & $0.5 \pm 0.36(5)$ & $1.0 \pm 0.40(5)$ \\
\hline 14 & $0.5 \pm 0.24(6)$ & $1.0 \pm 0.27(6)$ & $1.5 \pm 0.80$ & $1.3 \pm 0.61(6)$ \\
\hline 21 & $1.0 \pm 0.21(6)$ & $1.0 \pm 0.51(6)$ & $2.0 \pm 0.68(6)$ & $1.3 \pm 0.32(6)$ \\
\hline 28 & $0.8 \pm 0.44(6)$ & $1.5 \pm 0.46(6)$ & $2.0 \pm 0.85(6)$ & $0.8 \pm 0.41(6)$ \\
\hline \multicolumn{5}{|l|}{ Low } \\
\hline 7 & $1.0 \pm 0.33(6)$ & $1.0 \pm 0.17(6)$ & $1.5 \pm 0.52(6)$ & $1.3 \pm 0.35(6)$ \\
\hline 14 & $1.0 \pm 0.36(5)^{*}$ & $1.5 \pm 0.44(5)\left({ }^{\circ}\right)$ & $1.5 \pm 0.56(5)$ & $2.0 \pm 0.32(5)$ \\
\hline 21 & $1.5 \pm 0.33(6)^{*}$ & $2.0 \pm 0.52(6)$ & $2.3 \pm 0.52(5)$ & $2.3 \pm 0.65(6)^{*}$ \\
\hline 28 & $1.0 \pm 0.44(5)$ & $2.5 \pm 0.40(5)^{* *}$ & $1.5 \pm 0.32(5)$ & $1.5 \pm 0.68(5)$ \\
\hline \multicolumn{5}{|c|}{ Medium } \\
\hline 7 & $1.5 \pm 0.41(6)^{*}$ & $2.0 \pm 0.44(6)\left({ }^{\circ}\right)$ & $0.5 \pm 0.44(5)$ & $1.5 \pm 0.68(6)$ \\
\hline 14 & $1.5 \pm 0.20(5)^{* * *}$ & $2.0 \pm 0.44(5)\left({ }^{\circ}\right)$ & $1.5 \pm 0.96(5)$ & $1.5 \pm 0.60(5)$ \\
\hline 21 & $2.5 \pm 0.56(6)^{* * *}$ & $2.0 \pm 0.40(5)\left({ }^{\circ}\right)$ & $2.3 \pm 0.67(6)$ & $2.5 \pm 0.52(6)^{*}$ \\
\hline 28 & $1.8 \pm 0.28(4)^{*}$ & $2.8 \pm 0.61(4)^{*}$ & $2.0 \pm 0.33(3)$ & $1.0 \pm 0.44$ \\
\hline \multicolumn{5}{|l|}{ High } \\
\hline 7 & $1.5 \pm 0.24$ & $1.5 \pm 0.21(3)$ & $1.0 \pm 0.21$ & $2.0 \pm 0.33(3)$ \\
\hline 14 & $2.3 \pm 0.61(4)^{*}$ & $2.5 \pm 0.25(4)^{* *}$ & $2.8 \pm 0.50$ & $2.5 \pm 0.33(3)^{*}$ \\
\hline 21 & $2.3 \pm 0.28(6)^{* * *}$ & $2.0 \pm 0.33(6)^{*}$ & $2.8 \pm 0.71(6)$ & $2.8 \pm 0.52(6)^{* *}$ \\
\hline 28 & $2.0 \pm 0.40(5)^{* * *}$ & $3.0 \pm 0.32(5)^{* * *}$ & $1.5 \pm 0.76(5)$ & $1.5 \pm 0.20(5)$ \\
\hline
\end{tabular}

Changes were ranked from none (0) to severe (4) including intermediate ranks (e.g. $0.5,1.5$ ). Values are presented as median \pm mean absolute deviation for each time point; the number of fish assessed $(n)$ is given in parentheses. Significant differences between control and immersed fish are indicated $\left({ }^{*} p<0.05,{ }^{* *} p<0.01\right)$ for each time point. $\left({ }^{\circ}\right)$ Statistical significance, although mathematically correct, was assumed to have little biological relevance due to values that lie within the range of pathological changes observed in the initial- and sham-controls.

The degree of pathological change observed in the $P$. rubescens exposed fish was significantly different from the corresponding sham-control on day 14 and 21 in tank A; day 7, 14, 21 and 28 in tank B; and day 14, 21, and 28 in tank C (Table 4).

\subsubsection{Kidney}

Coregonids from the sham-control showed histopathological changes in the kidney within the normal range observed in coregonids of this age group. The observed changes included sporadic occurrence of apoptotic and regenerating cells and epithelial cell exfoliation. In fish of the initial control group, these changes appeared marginally more pronounced than in fish of the sham-control tank (Table 4).

In comparison to sham-controls, the kidneys of $P$. rubescens exposed fish showed more severe tubular degeneration including cell vacuolisation and cell shedding in the proxima as well as proteinaceous casts in the tubular lumina. Progressive proximal tubuli degeneration with exposure duration resulted in hyalinisation of tubuli epithelia and interstitial cell lyses (Fig. 3).

The degree of renal pathology observed in P. rubescens exposed fish was significantly different from the corresponding sham-controls on day 28 in tanks A and B and on day 14, 21 , and 28 in tank C (Table 4). Significant differences were also suggested for exposure as of day 7-21 in tanks A and B, however, these effects, although statistically correct, are assumed to have little biological relevance as the values lie within the range of pathological changes observable in the initial- and sham-controls.

\subsubsection{Hindgut}

Pathological alterations in the hindgut tissue of controls and exposed fish were characterised by the occurrence of frayed gut villi, exfoliation of epithelial cells, widespread cell lyses, infiltration of leucocytes and intraluminal protein cast deposition. Coregonids from all treatments (including initial- and shamcontrol) showed a sporadic Proteocephalus sp. infestation after the first week. The severity of infestation appeared to be comparable across all treatments and was no longer detectable at the end of the experiment (data not shown).

In contrast to the corresponding sham-controls, the gastrointestinal tissue of $P$. rubescens exposed fish showed an enhanced loss of the mucosal structure and extensive epithelial degeneration (Fig. 4). These pathological changes appeared to be most predominant after the third week of exposure, especially in fish of tank C. However, the range and severity of pathological change observed in $P$. rubescens exposed fish was not significantly different from the corresponding sham-controls (Table 4).

\subsubsection{Gills}

P. rubescens filaments were observable in gills of exposed fish ranging from single filaments in tank $A$ to accumulation filament bundles in fish of tanks B and C (Fig. 5)

Neither initial- or sham-control fish showed histopathologically relevant alterations in the gill beyond the normal range. In contrast, macroscopically the gills of $P$. rubescens exposed coregonids often appeared congested and frequently showed 

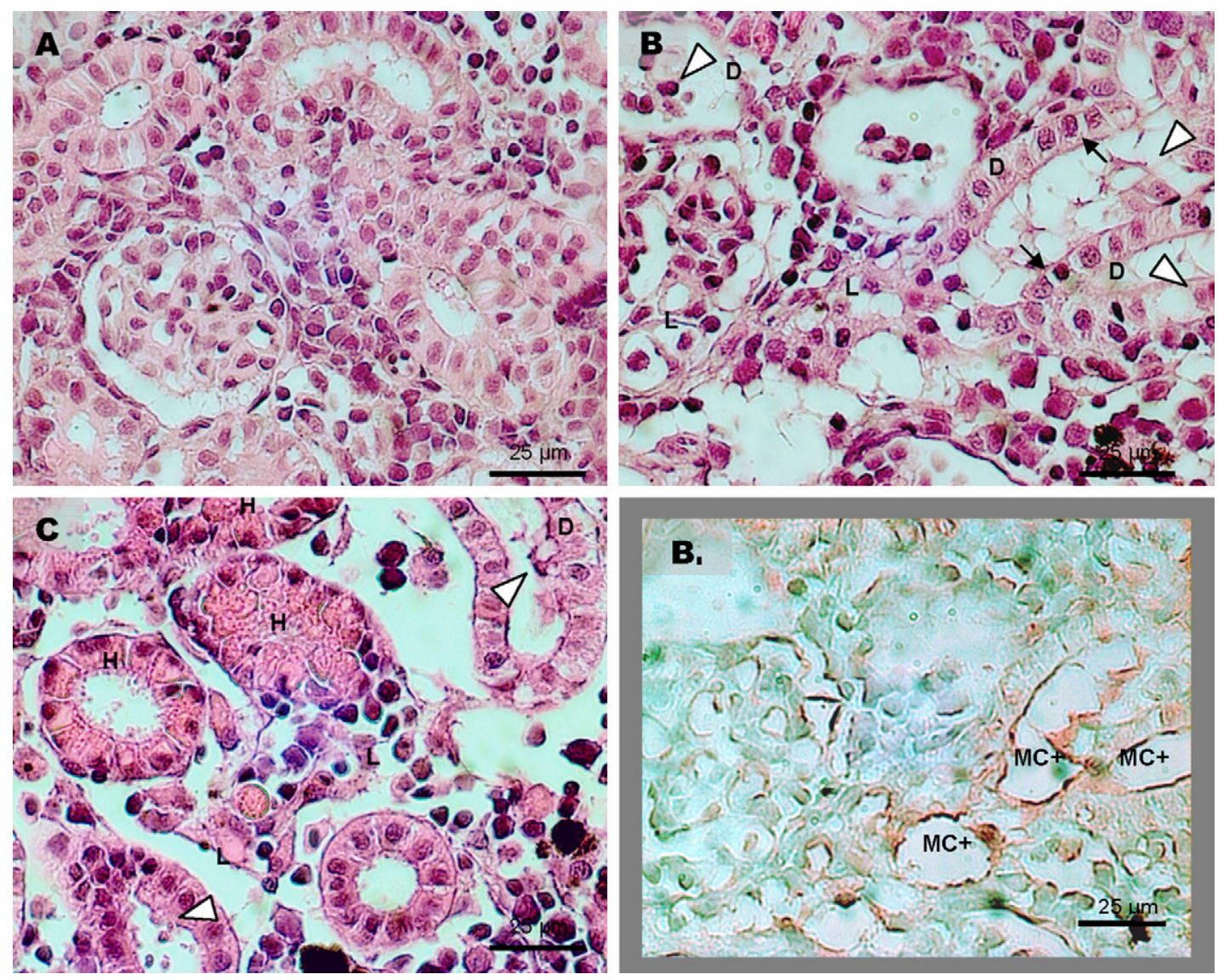

Fig. 3. Kidney tissue of a sham-control coregonid (A) and coregonids exposed to low (B) and high (C) P. rubescens cell densities for 28 days. Sections were stained with $\mathrm{H} \& \mathrm{E}(\mathrm{A}-\mathrm{C})$ or microcystin antibodies $\left(\mathrm{B}_{\mathrm{I}}\right)$. Exposed fish presented with enhanced tubuli degeneration (D) including cell vacuolisation (black arrows) and cell shedding in the proxima (white arrow heads), hyalinisation $(\mathrm{H})$ of tubular epithelia and interstitial cell lysis (L). Comparison of H\&E and immunostained sections $\left(\mathrm{B}\right.$ and $\mathrm{B}_{\mathrm{I}}$ ) demonstrates the presence of microcystin $(\mathrm{MC}+)$ in histologically altered tissue sections.

pathological changes including fusion, partial rupture and hyperplasia (clubbing) of the tips of the secondary lamellae, enhanced vacuolisation, oedema, apoptosis and focal necrosis in the lamellar epithelium and a partial dissociation of the epithelium sometimes leading to a exfoliation of epithelial cells into the gill mucus (Fig. 5). Parasitic Ichthyophthirius sp. were observable in the gills of all $P$. rubescens exposed fish after the third exposure week, and were particularly evident in fish of tank C.

The range and severity of pathological changes observed in P. rubescens exposed fish was significantly different from the
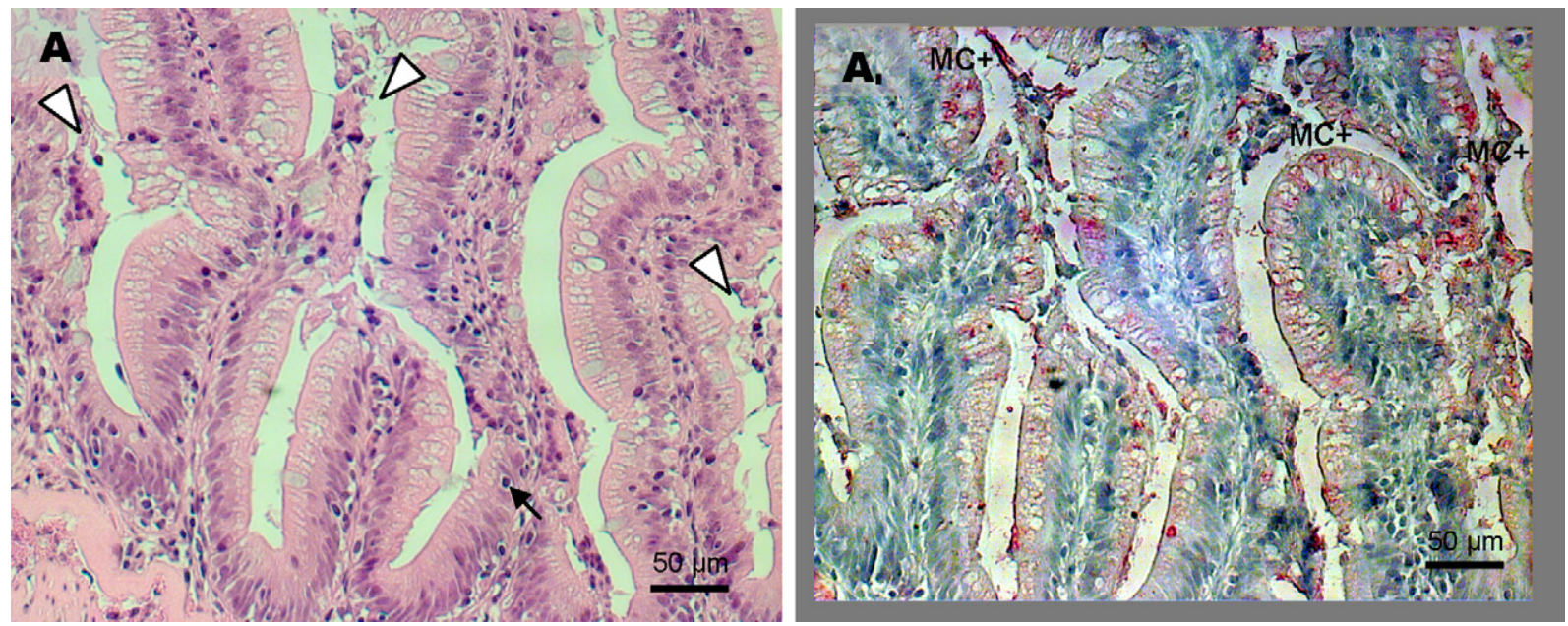

Fig. 4. Gastro-intestinal section of a coregonid exposed to high P. rubescens cell densities for 28 days. Sections were stained with H\&E (A) and microcystin antibodies $\left(\mathrm{A}_{\mathrm{I}}\right)$. Exposed fish presented with extensive epithelial degeneration and exfoliation (white arrow heads) of epithelial cells. Comparison of H\&E and microcystin-immunostained sections demonstrates the presence of microcystin $(\mathrm{MC}+)$ in histologically altered tissue sections. 


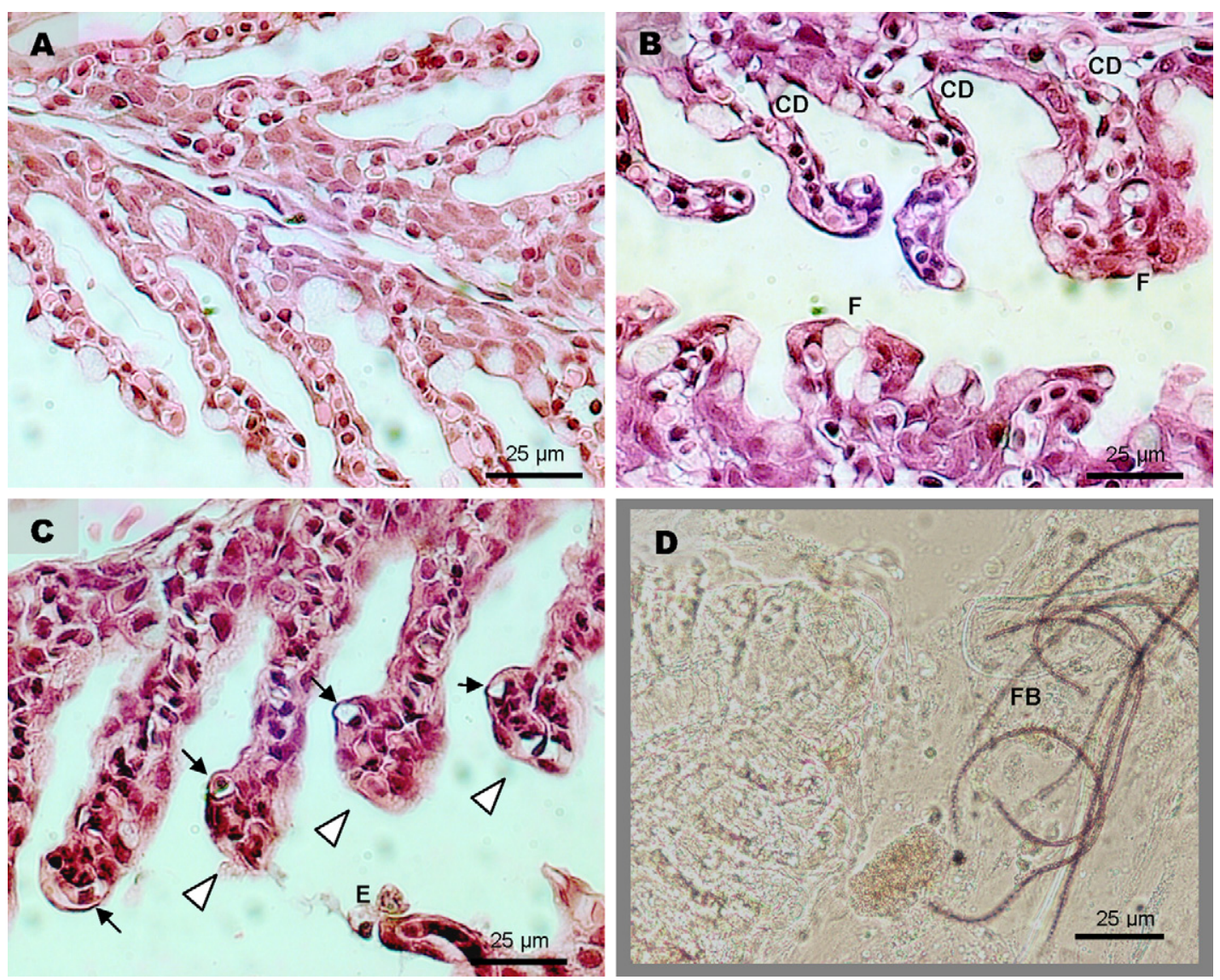

Fig. 5. Gill tissue of a sham-control coregonid (A) and coregonids exposed to low (B) and high (C and D) P. rubescens cell densities for 28 days. Sections A-C were stained with H\&E, while section D is a fresh (non-fixed) gill sample. Exposed fish presented with fusion (F), partial rupture and hyperplasia (clubbing) of the tips (white arrow heads) of the secondary lamellae, enhanced vacuolisation, focal necrosis (black arrows) in the lamellar epithelium and partial dissociation (CD) of the epithelium sometimes leading to exfoliation of epithelial cells (E). P. rubescens filaments were observable in gills of $P$. rubescens exposed fish ranging from single filaments to accumulation of filament bundles (FB).

corresponding sham-control tank as of the second week in tank $\mathrm{C}$, and after the third week in tanks A and B (Table 4). However, overall pathological scores were not significantly different between $P$. rubescens exposed and sham-control fish at the end of the experiment (Table 4).

Despite the reduced survival rate at the highest $P$. rubescens exposure treatment, none of the observed individual pathological changes were deemed to be of a severity that would imply being critical for coregonid survival.

\subsection{MC-immunohistology}

MC-immunohistology is summarised in Table 5. MCpositive staining was most distinct in the liver of the exposed coregonids, with regard to both the number of positive sections (individual fish) and the area of immunopositive staining. Livers of $P$. rubescens treated coregonids showed immunopositive staining predominantly consisting of dispersed positive foci after just 1 week of exposure in tanks B and $\mathrm{C}$ and as of week 2 of exposure in tank A (Fig. 2).

Only irregular immunopositive staining was detectable in kidney and gut tissue of fish in tank A, while immunopositive foci in kidney and gut tissue of fish of tanks B and C were detected consistently (Figs. 3 and 4).

MC immunopositive staining in liver, kidney and gut tissue co-localised to histopathological changes in the serially sectioned tissues (Figs. 2-4), whereas no MC staining was detectable in gills of any of the exposed fish.

\section{Discussion}

\subsection{Hydrological parameters, microcystin concentrations and $P$. rubescens cell densities}

Temperature and oxygen were stable and comparable between control and exposure tanks. Observed effects were therefore considered to be the consequence of $P$. rubescens exposure (and microcystin contaminations therein).

$P$. rubescens cell densities and corresponding microcystinLR equivalent concentrations (MC-LR equiv. $_{\text {. }}$ ) determined in the tanks throughout the experiments were stable, i.e., 1500 cells $/ \mathrm{ml}$

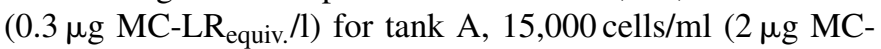

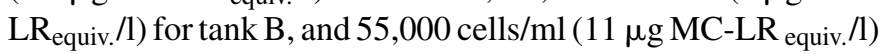
for tank $\mathrm{C}$. These cell densities represent the environmental situ- 
Table 5

Microcystin-immunohistochemical positivity in organ sections of coregonids, immersed in no (sham-control), low, medium and high $P$. rubescens cell densities up to 28 days

\begin{tabular}{|c|c|c|c|c|}
\hline Day & Liver & Kidney & Hindgut & Gill \\
\hline \multicolumn{5}{|c|}{ Initial } \\
\hline 0 & n.d. (4) & n.d. (4) & n.d. (4) & n.d. (4) \\
\hline \multicolumn{5}{|c|}{ Sham-control } \\
\hline 7 & n.d. (5) & n.d. (5) & n.d. (5) & n.d. (5) \\
\hline 14 & n.d. (4) & n.d. (4) & n.d. (4) & n.d. (4) \\
\hline 21 & n.d. (5) & n.d. (5) & n.d. (5) & n.d. (5) \\
\hline 28 & n.d. (4) & n.d. (4) & n.d. (4) & n.d. (4) \\
\hline \multicolumn{5}{|l|}{ Low } \\
\hline 7 & i.ip. (6) & i.ip. (6) & i.ip. (6) & n.d. (6) \\
\hline 14 & $+(5)$ & $+(5)$ & i.ip. (5) & n.d. (5) \\
\hline 21 & $+(6)$ & i.ip. (6) & i.ip. (6) & n.d. (6) \\
\hline 28 & $+(5)$ & i.ip. (5) & $+(5)$ & n.d. (5) \\
\hline \multicolumn{5}{|c|}{ Medium } \\
\hline 7 & $+(6)$ & i.ip. (6) & $+(6)$ & n.d. (6) \\
\hline 14 & $+(5)$ & $+(5)$ & $+(5)$ & n.d. (5) \\
\hline 21 & $+(6)$ & $+(5)$ & i.ip. (6) & n.d. (6) \\
\hline 28 & $++(4)$ & $+(4)$ & $+(4)$ & n.d. (4) \\
\hline \multicolumn{5}{|l|}{ High } \\
\hline 7 & $+(3)$ & $+(3)$ & $+(3)$ & n.d. (3) \\
\hline 14 & $++(4)$ & $+(4)$ & $+(4)$ & n.d. (3) \\
\hline 21 & $+(6)$ & $+(5)$ & $+(6)$ & n.d. (6) \\
\hline 28 & $+(5)$ & $+(5)$ & $+(4)$ & n.d. (5) \\
\hline
\end{tabular}

Immunopositive staining was ranked as none (n.d.), sporadic (+), cumulative $(++)$ and extensive $(+++)$. Classification is presented as median for each time point; the number of fish assessed $(n)$ is given in parentheses. When only a minority of assessed fish showed sporadic immunopositivity, these samples were denoted as irregular immunopositive (i.ip.). None of the assessed fish showed immunopositivity when denoted as not detectable (n.d.).

ations in pre-alpine lakes quite closely. Indeed, $P$. rubescens cell densities of more than 1500 cells/ml were permanently present throughout the entire period from January 2001 to November 2001 in Lake Ammersee, Germany (Ernst et al., 2001 and Ernst unpublished data). For Lake Bourget, France, Jacquet et al. (2005) reported $P$. rubescens cell densities up to 20,000 cells $/ \mathrm{ml}$ uniformly distributed during winter circulation and densities of more than 50,000 cells $/ \mathrm{ml}$ in the metalimnic layer during stratification in summer. MC-concentrations, predominantly dmRR variants, reached 6.7 $\mu \mathrm{g} \mathrm{MC} / \mathrm{l}$ (Jacquet et al., 2004).

\subsection{Behavioural observations and ventilation rates}

P. rubescens exposed coregonids appeared to actively avoid $P$. rubescens uptake as suggested by irregular gaping and regurgitation. This was especially prominent for coregonids exposed to medium $(15,000$ cells $)$ and high $(55,000$ cells $/ \mathrm{ml})$ cell densities. This observation is corroborated by similar findings by Tencalla and Dietrich (1997) in trout and Ernst et al. (2006a) in coregonids. In addition, fish exposed to the two highest densities showed increased startle response, hectic swimming and disorientation which appeared to become more pronounced with increasing exposure duration. As this type of stress response (Little, 2002) was reported earlier for fish exposed to $P$. rubescens (Ernst et al., 2006a) and other, non-filamentous cyanobacterial species, known to produce microcystins (Baganz et al., 1998, 2004; Carbis et al., 1996; Råbergh et al., 1991), it is suggested that this type of stress is unrelated to the filamentous form of $P$. rubescens but could be a direct consequence of exposure to microcystins and probably other $P$. rubescens components as summarised by Welker and von Döhren (2006). Indeed, this interpretation is supported by observations of Bury et al. (1996), who reported increased physiological stress, as measured by elevated plasma cortisol and plasma glucose levels, in brown trout (Salmo trutta L.) exposed to lysed toxic $M$. aeruginosa cells.

$P$. rubescens induced stress can also be inferred from the elevated ventilation observed in the exposed coregonids, as indicated by the significantly increased ventilation rates. Increased ventilation frequency is an indicator for enhanced stress, irrespective of the type of stressor present (Barreto and Volpato, 2004). Especially in the third exposure week elevated ventilation rates may have also resulted from the parasitical Ichthyophthirius sp. infestation, however, as significant increased ventilation rates were observed already prior to the Ichthyophthirius sp. infestation, the observed effect on the coregonids ventilation rate is assumed to be causally related to $P$. rubescens exposure. As increased ventilation rates were also observed in coregonid yearlings treated with a single oral dose of an environmentally relevant $P$. rubescens concentration (Ernst et al., 2006a), this may suggest that the increased ventilation is more likely the result of the systemic microcystin exposure rather than the mechanical irritation of $P$. rubescens filaments on the coregonid gills.

\subsection{Condition factor, fitness and mortality}

Growth and condition decreased in all fish in the study presented here, irrespective of the exposure type (sham-control or exposed). This may be ascribed to the fact that the planktivorous coregonids are non-domesticated fish with limited cultivation capabilities. However, stress related effects on fish fitness appeared more prominent with regard to the susceptibility of the individual treatment and control groups to ectoparasitic infestation and mortality. Indeed, the observed Ichthyophthirius infestation occurred only in the $P$. rubescens exposed fish and most severely in the highest treatment group, suggesting that the $P$. rubescens exposed coregonids were less resistant to the parasitic infestation. Despite that the pathological alterations were of limited severity, a general reduction of fitness was suggested by the fact that a dose-response relationship between filament density and fish mortality was noted.

\subsection{Histopathology}

The observed pathological changes in liver and kidney are characteristic of pathological lesions as described earlier for cyanobacteria and microcystin intoxications in coregonids (Ernst et al., 2006a) and other fish species (Carbis et al., 1996; Fischer and Dietrich, 2000; Råbergh et al., 1991; Tencalla and Dietrich, 1997). A causal relationship of tissue damage with the presence of microcystin-containing $P$. rubescens is additionally suggested by the observation that a high number of patholog- 
ical changes, whether observed in liver or kidney, were also immunopositive for MC as already shown for coregonids orally exposed to $P$. rubescens (Ernst et al., 2006a) and for trout and carp gavaged with M. aeruginosa (Fischer et al., 2000; Fischer and Dietrich, 2000).

In the medium dose treatment (tank B), overt liver pathology was already observable on day 7 of exposure. At this time point, a comparable pathology was also observable in liver of fish exposed to the highest $P$. rubescens density (tank C), although this was not statistically significant (primarily due to reduced sample numbers as a result of mortality).

The overall severity of pathological alterations observed in $P$. rubescens exposed coregonid kidneys was comparable to that observed in the livers, and was also dose- and time-dependent. This observation corroborates earlier findings by Fischer and Dietrich (2000) for carp orally exposed to bloom material containing microcystin.

In contrast to the pathology observed in the gut of coregonids orally exposed to P. rubescens (Ernst et al., 2006a) and carp intraperitoneally treated with $550 \mu \mathrm{g}$ MC-LR/kg b.w. (Råbergh et al., 1991), the degree of pathological changes observed in the hindgut of exposed coregonids in this study was not significantly different to that observed in the sham-control. However, a number of pathological changes co-localised with immunopositive staining for microcystin, suggesting that the observed pathology may be the consequence of the actual microcystin exposure.

An explanation for the comparatively high degree of tissue alteration in hindgut across all treatments is offered by the fact that coregonids from all treatments had sporadic Proteocephalus sp. infestation at the beginning of the experiment. As the progression and severity of the Proteocephalus infestation was comparable across all treatment groups (including initialand sham-control fish) the effect on the overall pathology examined in the study appears to be negligible. Proteocephalus sp. infestation is relatively common in salmonids of the pre-alpine lakes (Hanzelova et al., 1995). As the coregonids used in this experiment were wild-hatched, the observed Proteocephalus infestation appears to be inherent to this coregonid population and already present prior to the start of the experiment.

Gill pathology in $P$. rubescens exposed coregonids was slightly more severe than that observed in the concurrent control fish and was comparable to the changes reported for carp treated intraperitoneally with 25 and $50 \mu \mathrm{g} \mathrm{MC} / \mathrm{kg}$ b.w. or immersed in $1.7 \mu \mathrm{g} \mathrm{MC} / \mathrm{ml}$ (Carbis et al., 1996). However, the observed alterations in gill tissue were not microcystin-immunopositive. In view of the latter observation and the pathology described for an Anabaena sp. associated fish kill (Toranzo et al., 1990), it appears most likely that the gill pathology observed in the $P$. rubescens exposed coregonids resulted from mechanical abrasion and irritation from $P$. rubescens filaments and Ichthyophthirius infestation rather than microcystin associated effects. This interpretation is further corroborated by the fact that the severity of the observed gill pathology declined subsequent to therapeutic treatment with $4 \%$ saline and abatement of Ichthyophthirius infestation. Furthermore, in a previous study oral dosing of coregonids with $P$. rubescens resulted in no significant gill pathology (Ernst et al., 2006a). It is interesting to note, however, that the degree of Ichthyophthirius infestation appeared $P$. rubescens density dependent, thus suggesting that the severity of Ichthyophthirius infestation may have been dependent on the general fitness or immunological capability of the individual coregonids as already discussed above.

\section{Conclusion}

The present subchronic exposure experiment confirmed the initial hypothesis that subchronic and chronic exposure to low cyanobacterial cell densities and microcystin contaminations can enhance physiological stress and sustained pathological alterations in exposed coregonids. Moreover, the progression and severity of the observed adverse effects in P. rubescens exposed coregonids occurred in a dose-dependent manner, indicating that the higher the $P$. rubescens cell densities and hence the microcystin-concentrations, the more pronounced and earlier the occurrence of the adverse effects. However, even very low cell

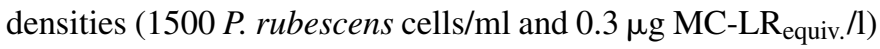
resulted in significant physiological stress, affecting coregonid fitness and resulting in substantial pathology, i.e., tissue damage and therefore sustained alteration in normal organ function. As all of the $P$. rubescens densities employed in this subchronic toxicity study represent realistic environmental situations in prealpine lakes which may be sustained for weeks or months, the subchronic effects described by the 4 week experiment presented here probably underestimate the potential adverse effects encountered by feral coregonid populations in lakes afflicted with $P$. rubescens blooms. This is particularly problematic, when fish cannot actively avoid $P$. rubescens exposure, e.g., during whole water-body blooms in winter circulation. Altogether, the study presented here supports the theory that stratified and dispersed $P$. rubescens blooms may be implicated in the observed reduced weight and hence fitness of coregonids in pre-alpine lakes such as Lake Ammersee.

\section{Acknowledgements}

We would like to thank RCC Ltd. for excellent technical support and Daniela Schmid for experimental assistance. The financial support and unrelenting interest of the Arthur and Aenne Feindt Foundation (Germany) in this topic is highly appreciated.

\section{References}

Baganz, D., Staaks, G., Pflugmacher, S., Steinberg, C.E., 2004. Comparative study of microcystin-LR-induced behavioral changes of two fish species, Danio rerio and Leucaspius delineatus. Environ. Toxicol. 19 (6), 564-570.

Baganz, D., Staaks, G., Steinberg, C., 1998. Impact of the cyanobacterial Toxin, microcystin-LR on behaviour of zebra fish, Danio rerio. Water Res. 32 (3), 948-952.

Barreto, R.E., Volpato, G.L., 2004. Caution for using ventilatory frequency as an indicator of stress in fish. Behav. Processes 66 (1), 43-51.

Barton, B.A., Morgan, J.D., Vijayan, M.M., 2002. Physiological and conditionrelated indicators of environmental stress in fish. In: Adams, S.M. (Ed.), Biological Indicators of Aquatic Ecosystem Stress,. American Society of Fisheries, Bethesda, Maryland, pp. 111-148. 
Bláha, L., Kopp, R., Simkova, K., Mares, J., 2004. Oxidative stress biomarkers are modulated in silver carp (Hypophthalmichthys molitrix Val) exposed to microcystin-producing cyanobacterial water bloom. Acta Vet. Brno 73, 477-482.

Braun, R., 1953. Vom "Burgunderblut". Naturkundliche Skizze.

Briand, J.F., Jacquet, S., Bernard, C., Humbert, J.F., 2003. Health hazards for terrestrial vertebrates from toxic cyanobacteria in surface water ecosystems. Vet. Res. 34, 361-377.

Bury, N.R., Eddy, F.B., Codd, G.A., 1996. Stress responses of brown trout, Salmo Trutta L., to the cyanobacterium, Microcystis aeruginosa. Environ. Toxicol. Water Qual. 11, 187-193.

Bury, N.R., Eddy, F.B., Codd, G.A., 1995. The effects of the cyanobacterium Microcystis aeruginosa, the cyanobacterial hapatotoxin microcystin-LR, and ammonia on growth rate and ionic regulation of brown trout. J. Fish Biol. $46,1042-1054$

Carbis, C., Rawlin, G., Mitchell, G., Anderson, J., McCauley, I., 1996. The histopathology of carp, Cyprinus carpio L., exposed to microcystin by gavage, immersion and intraperitoneal administration. J. Fish Dis. 19, 199-207.

Ernst, B., Hitzfeld, B.C., Dietrich, D.R., 2001. Presence of Planktothrix sp. and cyanobacterial toxins in Lake Ammersee, Germany and their impact on whitefish (Coregonus lavaretus L.). Environ. Toxicol. 16, 483-488.

Ernst, B., Hoeger, S.J., O'Brien, E., Dietrich, D.R., 2006a. Oral toxicity of the microcystin-containing cyanobacterium Planktothrix rubescens in European whitefish (Coregonus lavaretus). Aquat. Toxicol. 79, 31-40.

Ernst, B., Neser, S., O'Brien, E., Hoeger, S.J., Dietrich, D.R., 2006b. Determination of the filamentous cyanobacteria Planktothrix rubescens in environmental water samples using an image processing system. Harmful Algae 5, 281-289.

Fischer, W., Hitzfeld, B.C., Tencalla, F., Eriksson, J.E., Mikhailov, A., Dietrich, D.R., 2000. Microcystin-LR toxicodynamics, induced pathology, and immunohistochemical localisation in livers of blue-green algae exposed rainbow trout (Oncorhynchus mykiss). Toxicol. Sci. 54, 365-373.

Fischer, W.J., Dietrich, D.R., 2000. Pathological and biochemical characterisation of microcystin-induced hepatopancreas and kidney damage in carp. Toxicol. Appl. Pharmacol. 164, 73-81.

Fischer, W.J., Garthwaite, I., Miles, C.O., Ross, K.M., Aggen, J.B., Chamberlin, A.R., Towers, N.R., Dietrich, D.R., 2001. Congener-independent immunoassay for microcystins and nodularins. Environ. Sci. Technol. 35 (24), 4753-4757.

Gammeter, S., Forster, U., Zimmermann, U., 1997. Limnologische Untersuchungen im Zürichsee 1972-1996. Wasserversorgung Zürich (WVZ), Zürich.

Hanzelova, V., Snabel, V., Kralova, M., Fagerholm, H.P., 1995. A comparative study of fish parasites Proteocephalus exiguus and P. percae (Cestoda: Proteocephalidae): morphology, isoenzymes, and karyotype. Can. J. Zool. 73 (7), 1191-1198.

Hoeger, S.J., Schmid, D., Blom, J., Ernst, B., Dietrich, D.R. Specifics of microcystin-RR variants: consequences for analytical procedures and risk assessment. Environ. Sci. Technol., in press.

Hoeger, S.J., Hitzfeld, B.C., Dietrich, D.R., 2005. Occurrence and elimination of cyanobacterial toxins in drinking water treatment plants. Toxicol. Appl. Pharmacol. 203 (3), 231-242.

Jacquet, S., Berre Le, B., Paolini, G., Humbert, J.F., 2004. Variations of Planktothrix rubescens spatial distribution in Lac du Bourget (France). In: 6th International Conference on Toxic Cyanobacteria, Bergen, Norway, 21-27 June 2004.

Jacquet, S., Briand, J.F., Leboulanger, C., Avois-Jacquet, C., Oberhaus, L., Tassin, B., Vincon-Leite, B., Paolini, G., Druart, J.C., Anneville, O., Humbert, J., 2005. The proliferation of the toxic cyanobacterium Planktothrix rubescens following restoration of the largest natural French lake (Lac du Bourget). Harmful Algae 4, 651-672.
Jewel, M.A.S., Affan, A., Khan, S., 2003. Fish mortality due to cyanobacterial bloom in an aquaculture pond in Bangladesh. Pak. J. Biol. Sci. 6 (12), 1046-1050.

Jos, A., Pichardo, S., Prieto, A.I., Repetto, G., Vazquez, C.M., Moreno, I., Camean, A.M., 2005. Toxic cyanobacterial cells containing microcystins induce oxidative stress in exposed tilapia fish (Oreochromis sp) under laboratory conditions. Aquat. Toxicol. 72 (3), 261-271.

Krupa, D., Czernas, K., 2003. Mass appearance of cyanobacterium Planktothrix rubescens in Lake Piaseczno, Poland. Water Qual. Res. J. Can. 38 (1), $141-152$.

Kucklentz, V., Hamm, A., Jöhnk, K., Tsang-Pi, C., Morscheid, H., Roth, D., Schmidt-Halewicz, S., Morscheid, H., Mayr, C., 2001. Antwort bayerischer Voralpenseen auf verringerte Nährstoffzufuhr. Bayerisches Landesamt für Wasserwirtschaft, München, p. 272.

Landsberg, J.H., 2002. The effect of harmful algae blooms on aquatic organisms. Rev. Fish. Sci. 10 (2), 245-252.

Li, X.Y., Chung, I.K., Kim, J.I., Lee, J.A., 2005. Oral exposure to Microcystis increases activity-augmented antioxidant enzymes in the liver of loach (Misgurnus mizolepis) and has no effect on lipid peroxidation. Comp. Biochem. Physiol. Part C 141 (3), 292-296.

Little, E.E., 2002. Behavioral measures of environmental stressors in fish. In: Adams, M.S. (Ed.), Biological Indicators of Aquatic Ecosystem Stress. American Fisheries Society, Bethesda, Maryland, pp. 431-472.

Malbrouck, C., Kestemont, P., 2006. Effects of microcystins on fish. Environ. Toxicol. Chem. 25 (1), 72-86.

Råbergh, C.M.I., Bylund, G., Eriksson, J.E., 1991. Histopathological effects of microcystin-LR, a cyclic peptide toxin from the cyanobacterium (blue-green alga) Microcystis aeruginosa, on common carp (Cyprinus carpio L). Aquat. Toxicol. 20, 131-146.

Rippka, R., Deruelles, J., Waterbury, J.B., Herdman, M., Stanier, R.Y., 1979. Generic assignments, strain histories and properties of pure cultures of cyanobacteria. J. Gen. Microbiol. 111, 1-61.

Rodger, H.D., Turnbull, T., Edwards, C., Codd, G.A., 1994. Cyanobacterial (blue-green-algal) bloom associated pathology in brown trout, Salmo trutta L., in Loch Leven, Scotland. J. Fish Dis. 17 (2), 177-181.

Salmaso, N., 2000. Factors affecting the seasonality and distribution of cyanobacteria and chlorophytes: a case study from the large lakes south of the Alps with special reference to Lake Garda. Hydrobiologia 4381, $43-63$.

Sivonen, K., Jones, G., 1999. Cyanobacterial Toxins. In: Chorus, I., Bartram J. (Eds.), Toxic Cyanobacteria in Water. E \& FN Spon, London, pp. 41111.

Tencalla, F., 1995. Toxicity of cyanobacterial peptide toxins to fish [Ph.D. thesis] Swiss Federal Institute of Technology, Zürich.

Tencalla, F., Dietrich, D., 1997. Biochemical characterization of microcystin toxicity in trout (Oncorhynchus mykiss). Toxicon 35 (4), 583-595.

Tencalla, F.G., Dietrich, D.R., Schlatter, C., 1994. Toxicity of Microcystis aeruginosa peptide toxin to yearling rainbow trout (Oncorhynchus mykiss). Aquat. Toxicol. 30, 215-224.

Toranzo, A.E., Nieto, F., Barja, J.L., 1990. Mortality associated with cyanobacterial bloom in farmed rainbow trout in Galicia (Northwestern Spain). Bull. Eur. Assoc. Fish Pathol. 10 (4), 106-107.

Walsby, A.E., Avery, A., Schanz, F., 1998. The critical pressures of gas vesicles in Planktothrix rubescens in relation to the depth of winter mixing in Lake Zürich, Switzerland. J. Plankt. Res. 20 (7), 1357-1375.

Wehrli, B., Wüest, A., 1996. Zehn Jahre Seenbelüftung: Erfahrungen und Optionen. Zürich: Eidgenössische Anstalt für Wasserversorgung, Abwasserreinigung und Gewässerschutz, $128 \mathrm{p}$.

Welker, M., von Döhren, H., 2006. Cyanobacterial peptides-nature's own combinatorial biosynthesis. FEMS Microbiol. Rev. 30 (4), 530-563. 